\title{
Aktivitas antioksidan ekstrak etanol daun pecut kuda (Stachytarpheta jamaicensis (L.) Vahl) menggunakan metode ekstraksi berbasis gelombang ultrasonic
}

\author{
Rian Jumawardi ${ }^{*}$, Agus Dwi Ananto ${ }^{1}$, Rizqa Fersiyana Deccati ${ }^{1}$ \\ ${ }_{1}^{1}$ Program Studi Farmasi, Fakultas Kedokteran, Universitas Mataram, Mataram, Indonesia
}

DOI: https://doi.org/10.29303/sjp.v2i2.85

\section{Article Info}

Received : 2021-01-06

Revised : 2021-04-25

Accepted : 2021-09-30

\begin{abstract}
Abstrak: Free radical is an atom or molecule that has unpaired electrons, is reactive and unstable which can cause damage to cells and tissues. Secondary metabolite compounds in plants such as phenolics, flavonoids, tannins, and saponins can inhibit free radicals. One of the plants that has the potential as an antioxidant is a Stachytarpheta jamaicensis (L.) Vahl. The part of the plant that is often used as a medicinal ingredient by Indonesian people is the leaf part. The leaves of snakeweed are natural ingredients that are rich in phenolic compounds, flavonoids, tannins, and saponins. This study aims to determine the activity of free radical inhibition in the snakeweed leaf extract with Ultrasound Assisted Extraction method. Determination of free radical inhibition activity was examined using DPPH method at the concentration series of snakeweed leaf extracts of $60,65,70,75,80$, and 85 ppm. The comparison solution used was vitamin C made with a concentration series of 4, 5, $6,7,9$, and $11 \mathrm{ppm}$. The results showed that vitamin $C$ had a free radical inhibitory activity with an IC50 value of $9.40 \pm 0.07 \mathrm{ppm}$, while the extract of snakeweed leaf had free radical inhibition activity with an IC50 value of $74.32 \pm 0.71 \mathrm{ppm}$. Based on the IC50 value, the intensity of free radical inhibition activity in vitamin $C$ is classified as very strong and the extract of snakeweed leaf is strong.
\end{abstract}

Keywords: Pecut kuda leaf [Stachytarpheta jamaicensis (L.) Vahl], DPPH, IC 50, Ultrasound Assisted Extraction

Citation: Jumawardi, R., Ananto, A. D., \& Deccati, R. F. (2021). Aktivitas antioksidan ekstrak etanol daun pecut kuda (Stachytarpheta jamaicensis (L.) Vahl) menggunakan metode ekstraksi berbasis gelombang ultrasonic. Sasambo Journal of Pharmacy, 2(2), 80-86. doi: https://doi.org/10.29303/sjp.v2i2.85

\section{Pendahuluan}

Radikal bebas adalah suatu atom atau molekul yang memiliki elektron tidak berpasangan, bersifat tidak stabil dan sangat reaktif, akibatnya radikal bebas akan menarik elektron dari molekul-molekul di dalam sel dan menyebabkan kerusakan pada sel dan jaringan. Radikal bebas dapat menimbulkan berbagai penyakit, seperti diabetes mellitus, penyakit parkinson, emfisema, gagal ginjal akut, penuaan, dan kanker. Oleh karena itu, tubuh membutuhkan antioksidan yang dapat menstabilkan radikal bebas (Qazi \& Khursid, 2018).

Antioksidan dapat diklasifikasikan sebagai antioksidan sintetik dan alami. Salah satu contoh antioksidan sintetik seperti suplemen injeksi vitamin C yang digunakan untuk mengobati pasien kanker. Dalam salah satu penelitian, peneliti menggambarkan dua efek samping serius pengobatan vitamin C sintetik yang diberikan dengan cara injeksi untuk pasien 
kanker, yaitu batu ginjal dan hipokalemia (Riordan et al., 2005). Selain itu, penelitian yang dilakukan oleh Dean (2004), yang melibatkan orang dewasa mengonsumsi suplemen vitamin C $1.000 \mathrm{mg}$ dua kali sehari selama enam hari, jumlah oksalat yang mereka keluarkan meningkat sebesar 20\%. Oksalat dapat berikatan dengan mineral untuk membentuk kristal yang dapat menyebabkan pembentukan batu ginjal. Kekhawatiran adanya kemungkinan efek samping dari antioksidan sintetik tersebut menyebabkan antioksidan alami dari bahan alam terus dieksplorasi.

Tanaman di Indonesia yang mempunyai potensi sebagai antioksidan alami adalah pecut kuda [Stachytarpheta jamaicensis (L.) Vahl]. Tanaman pecut kuda digunakan masyarakat Indonesia untuk mengobati infeksi dan batu saluran kencing, diuretik, rheumatik, sakit tenggorokan, haid tidak teratur, keputihan dan hepatitis. Bagian tanaman yang digunakan antara lain daun, bunga, dan akar (Dalimartha, 2000). Daun tanaman ini mengandung beberapa senyawa metabolit sekunder seperti terpenoid, flavonoid, fenol, saponin serta tannin (Oliva \& Teresita, 2015). Dalam penelitian yang dilakukan oleh Ololade (2017), ekstrak metanol daun pecut kuda berpotensi sebagai penghambat radikal bebas menggunakan metode DPPH dengan nilai $\mathrm{IC}_{50}$ (inhibitory concentration 50 ) $5,0 \mu \mathrm{g} / \mathrm{mL}$.

Maesaroh et al (2018) melaporkan bahwa metode DPPH merupakan metode uji aktivitas antioksidan yang paling efektif karena memiliki nilai $\mathrm{IC}_{50}$ terendah yaitu 2,77 $\mathrm{mg} / \mathrm{L}$ untuk asam askorbat, sedangkan metode FRAP dan FIC berturut-turut dengan nilai $\mathrm{IC}_{50}$ 7,25 mg/L dan 210,51 mg/L. Metode DPPH dipilih pada pengujian aktivitas antioksidan ini karena memiliki prosedur yang mudah dan cepat untuk mengevaluasi aktivitas penangkapan radikal oleh antioksidan. Radikal DPPH merupakan radikal yang stabil dan memiliki serapan maksimum pada panjang gelombang $517 \mathrm{~nm}$.

Berdasarkan latar belakang tersebut, maka perlu dilakukan uji aktivitas antioksidan ekstrak etanol daun pecut kuda (Stachytarpheta jamaicensis (L.) Vahl) menggunakan metode ekstraksi berbasis gelombang ultrasonic

\section{Material dan Metode}

\section{Alat dan bahan}

Alat-alat yang digunakan pada penelitian adalah alat-alat gelas (Iwaki), blender (Kirin), hotplate (Labnet), ayakan mesh 10, mikropipet, mixer (Vortex), oven (Memmer), rotary evaporator (Heidolph), spektrofotometri UV-Vis (Specord 200), sonikator (Elmasonic), dan timbangan analitik (Ohaus).
Bahan-bahan dalam penelitian ini adalah daun pecut kuda (Stachytarpheta jamaicensis (L.) Vahl), etanol 96\% teknis (Merck), etanol p.a (Merck), FeCl3 3\% (Merck), $\mathrm{FeCl} 31 \%$ (Merck), serbuk Mg (Merck), $\mathrm{HCl}$ pekat (Merck), HCl $2 \mathrm{~N}$ (Merck), aquades, DPPH (1,1difenil-2-pikrilhidrazil) p.a (Sigma) dan vitamin C (Merck).

\section{Prosedur kerja}

\section{Pengumpulan bahan}

Sampel daun pecut kuda diambil dari Desa Lingsar, Kecamatan Narmada, Kabupaten Lombok Barat, Provinsi Nusa Tenggara Barat. Sampel dipetik langsung pada pohonnya dan tidak boleh tersentuh langsung dengan tanah. Jumlah sampel yang diambil adalah $3 \mathrm{~kg}$.

\section{Determinasi tumbuhan}

Determinasi dilakukan di Laboratorium Program Studi Biologi, Fakultas Matematika dan Ilmu Pengetahuan Alam, Universitas Mataram.

\section{Preparasi sampel}

Daun pecut kuda yang terkumpul, selanjutnya disortasi, dicuci, dijemur di bawah sinar matahari dengan ditutup kain hitam hingga sampel kering. Sampel tersebut kemudian disortasi kering, diblender sampai menjadi serbuk dan diayak dengan ukuran nomor mesh 10. Hasil ayakan disimpan pada wadah tertutup untuk digunakan lebih lanjut.

\section{Penentuan kadar air simplisia}

Sebanyak 2 g simplisia pada cawan porselen dipanaskan dengan oven pada suhu $105^{\circ} \mathrm{C}$ selama 30 menit dan dikeringkan hingga mencapai bobot tetap. Kadar air yang baik adalah $<10 \%$ dan dapat dihitung menggunakan persamaan (1) (Depkes RI, 2000).

Kadar Air $=\frac{(b-(c-a))}{b} \times 100 \%$

Keterangan:

$\mathrm{a}=$ Berat cawan

$\mathrm{b}=$ Berat sampel

$\mathrm{c}=$ Berat cawan + sampel

\section{Ekstraksi}

Sebanyak $100 \mathrm{~g}$ serbuk simplisia dicampurkan dengan pelarut etanol 96\% (500 mL) perbandingan (1:5) dalam gelas piala $1 \mathrm{~L}$ kemudian disonikasi dalam ultrasonic batch pada frekuensi $20 \mathrm{kHz}$ dengan kontrol suhu $30^{\circ} \mathrm{C}$. Ekstraksi dilakukan selama 60 menit dan diaduk setiap 15 menit, kemudian disaring. Filtrat diekstrak kembali dengan langkah yang sama sebanyak 3 kali. Semua filtrat digabungkan, kemudian pelarut diuapkan dengan rotary evaporator pada suhu $40^{\circ} \mathrm{C}$, 
sehingga diperoleh ekstrak kental. Selanjutnya dihitung persentase rendemen yang diperoleh dari hasil perhitungan berat ekstrak dibagi dengan berat awal sampel (berat simplisia) dalam satuan persen. Perhitungan menggunakan persamaan(2).

Rendemen ekstrak $(\%)=\frac{\text { Berat ekstrak }}{\text { Berat awal sampel }} \times 100 \% \ldots$.

\section{Identifikasi metabolit sekunder Identifikasi flavonoid}

Identifikasi flavonoid dilakukan dengan cara dimasukkan 0,1 g ekstrak daun pecut kuda ke dalam tabung reaksi, lalu ditambahkan $1 \mathrm{ml} \mathrm{HCl}$ pekat, $1 \mathrm{ml}$ amilalkohol, dan 0,1 g serbuk $\mathrm{Mg}$ kemudian dikocok dengan kuat. Uji positif flavonoid ditandai dengan terbentuknya warna merah, kuning, atau jingga pada lapisan amilalkohol (Dash, 2016).

\section{Identifikasi fenolik}

Identifikasi fenolik dilakukan dengan cara dimasukkan 0,5 g ekstrak daun pecut kuda ke dalam tabung reaksi, ditambahkan $5 \mathrm{~mL}$ aquades, lalu panaskan sampai mendidih selama 2 menit, dinginkan dan disaring. Filtrat yang diperoleh kemudian dimasukkan ke dalam tabung reaksi, ditambah 2 tetes larutan $\mathrm{FeCl}_{3}$ 1\% akan terbentuk warna hijau atau hitam kehijauan menunjukkan adanya fenolik (Raaman, 2006).

\section{Identifikasi tanin}

Identifikasi tanin dilakukan dengan cara dilarutkan 0,1 g ekstrak daun pecut kuda dalam $10 \mathrm{ml}$ aquades dan didihkan. Sampel disaring, filtrat $(2 \mathrm{ml})$ ditambah dengan $1 \mathrm{ml} \mathrm{FeCl}_{3} 3 \%$. Adanya endapan hijau kehitaman menandakan adanya tanin (Raaman, 2006).

\section{Identifikasi saponin}

Identifikasi saponin dilakukan dengan cara dimasukkan $1 \mathrm{mg}$ ekstrak daun pecut kuda ke dalam tabung reaksi, lalu ditambahkan dengan $10 \mathrm{~mL}$ air dan dikocok kuat-kuat selama 10 menit sampai terbentuk busa. Pada penambahan 1 tetes $\mathrm{HCl} 2 \mathrm{~N}$, apabila buih tidak hilang, maka ekstrak positif mengandung saponin (Raaman, 2006).

\section{Uji aktivitas antiradikal bebas Pembuatan larutan DPPH (40 $\mu \mathrm{g} / \mathrm{mL})$}

Pembuatan larutan stok dilakukan dengan cara ditimbang seksama 10 mg DPPH (BM 394,33). Lalu dilarutkan dengan etanol p.a, kemudian ditempatkan dalam labu ukur $10 \mathrm{~mL}$ yang dilapisi dengan aluminium foil. Dicukupkan pelarutnya hingga tanda batas kemudian kocok hingga homogen dan diperoleh larutan DPPH dengan konsentrasi $1000 \mu \mathrm{g} / \mathrm{mL}$. Larutan tersebut kemudian diencerkan dengan cara dipipet $2 \mathrm{~mL}$ larutan DPPH konsentrasi $1000 \mu \mathrm{g} / \mathrm{mL}$ ke dalam labu ukur $50 \mathrm{~mL}$ dan dicukupkan pelarutnya hingga tanda batas kemudian kocok hingga homogen dan diperoleh larutan DPPH dengan konsentrasi 40 $\mu \mathrm{g} / \mathrm{mL}$.

\section{Penentuan panjang gelombang DPPH}

Dimasukkan $3 \mathrm{~mL}$ larutan DPPH $40 \mu \mathrm{g} / \mathrm{mL}$ ke dalam tabung reaksi. Lalu tambahkan etanol p.a sebanyak $2 \mathrm{~mL}$ dan dihomogenkan dengan cara divortex, dan tabung reaksi ditutup dengan aluminium foil. Larutan tersebut kemudian diinkubasi dalam ruangan gelap selama 30 menit. Blanko yang digunakan yaitu etanol p.a. Selanjutnya ditentukan spektrum serapannya menggunakan spektrofotometer UV-Vis pada panjang gelombang 400-800 $\mathrm{nm}$ dan ditentukan panjang gelombang maksimumnya.

\section{Penentuan Operating Time}

Penentuan operating time dilakukan dengan cara $2 \mathrm{~mL}$ larutan vitamin C 5 ppm ditambah $3 \mathrm{~mL}$ larutan DPPH $40 \mu \mathrm{g} / \mathrm{mL}$. Larutan tersebut kemudian divortex dan diukur pada menit ke $0,5,10,15,20,25$, $30,35,40,45$ dan 50 menit pada panjang gelombang maksimum yang didapatkan. Blanko yang digunakan yaitu vitamin $\mathrm{C}$. Menit yang menghasilkan absorbansi peredaman radikal bebas DPPH paling stabil merupakan operating time (Mulangsri et al., 2017).

\section{Pengukuran absorbansi kontrol}

Dimasukkan $3 \mathrm{~mL}$ DPPH $40 \mu \mathrm{g} / \mathrm{mL}$ dan ditambahkan $2 \mathrm{~mL}$ etanol p.a. Larutan tersebut kemudian divortex selama 30 detik dan didiamkan selama operating time. Blanko yang digunakan yaitu etanol p.a. Pengerjaan dilakukan pada wadah gelap dan kondisi yang terhindar dari cahaya. Larutan dibaca absorbansinya pada panjang gelombang maksimum.

\section{Pengukuran absorbansi larutan pembanding}

Ditimbang vitamin C sebanyak $10 \mathrm{mg}$, dilarutkan dengan etanol p.a, dimasukkan ke dalam labu ukur dan ditambahkan pelarut hingga $10 \mathrm{~mL}$, kemudian dikocok hingga homogen. Selanjutnya dibuat seri konsentrasi 4, 5, 6, 7, 9 dan 11 ppm. Untuk pengukuran absorbansi, masing-masing seri konsentrasi dipipet sebanyak $2 \mathrm{~mL}$ dimasukkan ke dalam tabung reaksi yang ditutup aluminium foil, kemudian ditambahkan $3 \mathrm{~mL}$ DPPH $40 \mu \mathrm{g} / \mathrm{mL}$. Selanjutnya larutan tersebut divortex selama 30 detik dan didiamkan selama operating time. Blanko yang digunakan yaitu $2 \mathrm{~mL}$ etanol p.a dan $3 \mathrm{~mL}$ larutan vitamin $C$ masing-masing konsentrasi. Pengerjaan dilakukan pada wadah gelap dan kondisi yang 
terhindar dari cahaya. Larutan dibaca absorbansinya pada panjang gelombang maksimum. Pengerjaan direplikasi sebanyak 3 kali.

\section{Pengukuran absorbansi larutan ekstrak daun pecut kuda}

Ditimbang ekstrak sebanyak $10 \mathrm{mg}$, dilarutkan dengan etanol p.a, dimasukkan ke dalam labu ukur dan ditambahkan pelarut hingga $10 \mathrm{~mL}$, kemudian dikocok hingga homogen. Selanjutnya dibuat seri konsentrasi 60, 65, 70, 75, 80 dan 85 ppm. Untuk pengukuran absorbansi, masing-masing seri konsentrasi dipipet $2 \mathrm{~mL}$ dimasukkan ke dalam tabung reaksi yang ditutup aluminium foil, kemudian ditambahkan $3 \mathrm{~mL}$ DPPH $40 \mu \mathrm{g} / \mathrm{mL}$. Selanjutnya larutan tersebut divortex selama 30 detik dan didiamkan selama operating time. Blanko yang digunakan yaitu $2 \mathrm{~mL}$ etanol p.a dan $3 \mathrm{~mL}$ larutan ekstrak pecut kuda masing-masing konsentrasi. Pengerjaan dilakukan pada wadah gelap dan kondisi yang terhindar dari cahaya. Larutan dibaca absorbansinya pada panjang gelombang maksimum. Pengerjaan direplikasi sebanyak 3 kali.

\section{Penentuan nilai $\mathrm{IC}_{50}$}

Nilai $\mathrm{IC}_{50}$ dihitung berdasarkan persentase inhibisi terhadap radikal DPPH dari masing-masing konsentrasi larutan uji serta larutan sampel. Persentase inhibisi dapat dihitung menggunakan persamaan (3).

$\%$ Inhibisi $=\frac{\text { Absorbansi kontrol-Absorbansi sampel }}{\text { Absorbansi kontrol }} \times 100 \% \ldots$.

Hasil perhitungan dari aktivitas antioksidan dimasukkan kedalam persamaan garis $\mathrm{y}=\mathrm{a}+\mathrm{bx}$ dengan konsentrasi (ppm) sebagai absis (sumbu $\mathrm{x}$ ) dan nilai persentase aktivitas antioksidan sebagai ordinatnya (sumbu y). Nilai IC $\mathrm{IC}_{50}$ dari perhitungan pada saat persentase aktivitas antioksidan sebesar $50 \%$ akan diperoleh dari persamaan garis (Chandra et al., 2019).

\section{Hasil dan Pembahasan}

Tanaman yang digunakan pada penelitian ini adalah tanaman pecut kuda yang diperoleh dari Desa Lingsar - Kabupaten Lombok Barat dengan lokasi titik koordinat S 858651" E 116 $16268^{\prime \prime}$. Bagian tanaman yang digunakan adalah daun. Dalam pembuatan simplisia daun pecut kuda, mula-mula daun pecut kuda dipetik sebanyak $3 \mathrm{~kg}$ dan disortasi basah, kemudian dicuci bersih. Sampel selanjutnya dikeringkan dengan cara dijemur di bawah sinar matahari langsung menggunakan wadah pengering dan ditutup dengan kain hitam. Tujuan ditutupnya sampel dengan kain hitam adalah untuk menyerap sinar ultraviolet yang bersifat merusak serta dapat memberikan penyebaran panas secara merata dalam proses pengeringan, sehingga kerusakan dan dekomposisi senyawa yang terkandung dalam sampel dapat dicegah (Prasetyo \& Inoriah, 2013). Proses pengeringan sampel dimaksudkan untuk menurunkan kandungan air. Menurut Departemen Kesehatan RI, (2000), kadar air yang baik adalah $<10 \%$ dan pada penelitian ini diperoleh kadar air sampel sebesar 7,25\%.

Ekstraksi dilakukan menggunakan metode ekstraksi yang memanfaatkan gelombang ultrasonik atau disebut sonikasi (Ultrasound Assisted Extraction). Metode ekstraksi sonikasi dipilih karena metode ini membutuhkan waktu yang singkat dan tidak membutuhkan jumlah pelarut yang banyak untuk mengekstraksi senyawa bioaktif. Selain itu, pada penelitian ini berfokus pada senyawa yang berperan sebagai antioksidan, seperti fenolik, flavonoid, tanin dan saponin, dimana senyawa-senyawa tersebut bersifat termolabil sehingga sonikasi merupakan teknik ekstraksi yang tepat (Kumoro, 2015). Pelarut dipisahkan dengan menggunakan vaccum rotary evaporator untuk mendapatkan ekstrak kental. Persentase rendemen yang diperoleh sebesar $25,78 \%$.

Tabel 1. Hasil identifikasi senyawa metabolit sekunder

Metabolit sekunder Hasil

$\begin{array}{ll}\text { Fenolik } & + \\ \text { Flavonoid } & + \\ \text { Tanin } & + \\ \text { Saponin } & +\end{array}$

Identifikasi senyawa metabolit sekunder dalam penelitian ini dilakukan untuk mengetahui ada atau tidaknya senyawa fenolik, flavonoid, tanin, dan saponin di dalam ekstrak etanol daun pecut kuda. Pengujian keempat senyawa tersebut dalam penelitian ini dikarenakan sifat dari senyawa tersebut berpotensi sebagai penangkap radikal bebas. Hasil dari identifikasi metabolit sekunder dalam ekstrak daun pecut kuda dapat dilihat pada Tabel 1. Hasil identifikasi yang sama juga ditunjukkan pada penelitian yang dilakukan oleh Oliva \& Teresita (2015), yang menyatakan bahwa ekstrak daun pecut kuda mengandung beberapa senyawa metabolit sekunder seperti flavonoid, fenol, saponin serta tannin.

Pengujian aktivitas penghambatan radikal bebas dilakukan menggunakan metode DPPH. DPPH sendiri adalah singkatan umum untuk senyawa kimia organik 2,2-difenil-1-pikrilhidrazil. DPPH ini adalah bubuk kristal berwarna gelap yang terdiri dari molekul radikal bebas. Metode DPPH merupakan metode yang mudah, cepat dan sensitif untuk pengujian aktivitas antioksidan senyawa tertentu atau ekstrak tanaman. 
Selain itu, proses pengerjaannya sederhana dan menggunakan sampel dalam jumlah sedikit (Mulangsri et al., 2017).

Langkah pertama pada pengujian aktivitas penghambatan radikal bebas menggunakan metode DPPH adalah dengan menetapkan panjang gelombang maksimum. Penentuan panjang gelombang maksimum ditentukan dengan cara melakukan scanning DPPH 40 $\mu \mathrm{g} / \mathrm{mL}$ dengan menggunakan volume $3 \mathrm{ml}$ DPPH 40 $\mu \mathrm{g} / \mathrm{mL}$. Setelah itu, ditambahkan dengan metanol $2 \mathrm{ml}$ dan dilakukan scanning pada rentang panjang gelombang 400-800 nm. Hasil yang diperoleh dari uji penentuan panjang gelombang maksimum DPPH adalah $517 \mathrm{~nm}$. Berdasarkan literatur, panjang gelombang maksimum DPPH bervariasi yaitu $515 \mathrm{~nm}$, $516 \mathrm{~nm}, 517 \mathrm{~nm}, 518 \mathrm{~nm}$, dan $520 \mathrm{~nm}$ (Molyneux, 2004). Dalam penelitian ini, diketahui bahwa hasil untuk operating time dari DPPH diperoleh waktu 25 menit, dikarenakan pada waktu 25 menit absorbansi berada pada kondisi stabil. Sehingga pengukuran larutan uji dapat diukur pada rentang waktu 25 menit untuk memperoleh hasil linier.

Pengukuran dimulai dengan menentukan absorbansi kontrol yang merupakan campuran DPPH dan etanol. Selanjutnya, pengukuran sampel dilakukan pada enam seri konsentrasi. Penggunaan enam seri konsentrasi ini bertujuan untuk membuat kurva baku dari sampel sehingga diperoleh persamaan regresi linear. Setiap pengukuran direplikasi sebanyak tiga kali untuk memastikan pengukuran dilakukan secara tepat, kemudian hasil yang didapatkan tersebut dibuat persamaan regresinya, sehingga dari hasil regresi tersebut didapatkan nilai $\mathrm{IC}_{50}$ masing-masing replikasi, selanjutnya dihitung rata-rata nilai $\mathrm{IC}_{50}$ tersebut. Dari rata-rata nilai $\mathrm{IC}_{50}$ dapat dilihat seberapa besar aktivitas penghambatan radikal bebas sampel ekstrak daun pecut kuda dan vitamin $C$ sebagai pembanding.

Pengukuran absorbansi vitamin $\mathrm{C}$ dilakukan pada konsentrasi 4, 5, 6, 7, 9 dan 11 ppm. Hasil dari pengukuran absorbansi masing-masing konsentrasi pada tiap replikasi dihitung persentase inhibisinya terhadap DPPH. Nilai $\mathrm{IC}_{50}$ merupakan konsentrasi senyawa penghambat radikal bebas yang dibutuhkan untuk menangkap radikal bebas DPPH sebanyak 50\%. Nilai $\mathrm{IC}_{50}$ dapat diperoleh dari persamaan regresi linier yang menyatakan hubungan antara konsentrasi sampel (x) dengan persentase inhibisi $(y)$, sehingga diperoleh persamaan regresi linear $y=b x+a$. Konsentrasi sampel (x) yang dibutuhkan untuk menangkap radikal bebas DPPH sebanyak 50\% ditentukan dengan cara memasukkan angka 50 sebagai y dalam persamaan regresi linier (Chandra et al., 2019). Persamaan regresi linear yang diperoleh pada replikasi 1,2 , dan 3 berturut-turut yaitu $y=5.4091 x-1.0088\left(R^{2}=0.9892\right)$, y $=5.7629 x-4.4356\left(R^{2}=0.9898\right)$, dan $y=5.9944 x-5.7842$
$\left(R^{2}=0.9789\right)$. Nilai $R^{2}$ mendekati 1 menunjukkan bahwa kurva memiliki linearitas yang baik. Hasil perhitungan $\mathrm{IC}_{50}$ vitamin $\mathrm{C}$ pada tiap replikasi dapat dilihat pada Tabel 2.

Tabel 2. Nilai $\mathrm{IC}_{50}$ vitamin $\mathrm{C}$

\begin{tabular}{|c|c|c|c|}
\hline \multicolumn{3}{|c|}{$\mathrm{IC}_{50}(\mathrm{ppm})$} & Rerata $\mathrm{IC}_{50} \pm \mathrm{SD}(\mathrm{ppm})$ \\
\hline R1 & $\mathrm{R} 2$ & R3 & \\
\hline 9,43 & 9,44 & 9,31 & $9,40 \pm 0,07$ \\
\hline
\end{tabular}

Pengukuran aktivitas penghambatan radikal bebas ekstrak etanol daun pecut kuda menggunakan variasi konsentrasi 60, 65, 70, 75, 80 dan 85 ppm. Berdasarkan Tabel 3 diketahui bahwa persentase inhibisi meningkat seiring dengan meningkatnya konsentrasi sampel dikarenakan semakin banyak senyawa pada sampel yang menghambat radikal bebas DPPH. Persentase inhibisi merupakan salah satu parameter yang menunjukkan kemampuan suatu antioksidan dalam menghambat radikal bebas (Mulangsri et al., 2017).

Tabe1 3. Hasil persentase inhibisi oleh ekstrak etanol daun pecut kuda

\begin{tabular}{llll}
\hline \multirow{2}{*}{ Konsentrasi (ppm) } & \multicolumn{3}{c}{ \% Inhibisi } \\
\cline { 2 - 4 } & R1 & R2 & R3 \\
\hline 60 & 37.21 & 35.51 & 35.89 \\
65 & 39.20 & 41.17 & 39.50 \\
70 & 45.70 & 46.82 & 49.26 \\
75 & 49.58 & 50.46 & 51.58 \\
80 & 55.80 & 57.11 & 54.44 \\
85 & 58.21 & 61.04 & 60.19 \\
\hline
\end{tabular}

Persamaan regresi linear yang diperoleh pada replikasi 1,2 , dan 3 berturut-turut yaitu $\mathrm{y}=0.9067 \mathrm{x}$ $18.122\left(R^{2}=0.9832\right), y=1.0235 x-25.518\left(R^{2}=0.9956\right)$, dan $\mathrm{y}=0.9637 \mathrm{x}-21.388\left(\mathrm{R}^{2}=0.9627\right)$. Nilai $\mathrm{R}^{2}$ mendekati 1 menunjukkan bahwa kurva memiliki linearitas yang baik. Nilai $\mathrm{IC}_{50}$ ekstrak daun pecut kuda dapat dilihat pada Tabel 4.

Tabel 4. Nilai $\mathrm{IC}_{50}$ ekstrak daun pecut kuda

\begin{tabular}{cccc}
\hline \multicolumn{3}{c}{$\mathrm{IC}_{50}(\mathrm{ppm})$} & \multirow{2}{*}{ Rerata $\mathrm{IC}_{50} \pm \mathrm{SD}(\mathrm{ppm})$} \\
\hline $\mathrm{R} 1$ & $\mathrm{R} 2$ & $\mathrm{R} 3$ & \\
\hline 75,13 & 73,78 & 74,07 & $74,32 \pm 0,71$ \\
\hline
\end{tabular}

Berdasarkan hasil penelitian, hasil pengujian aktivitas penghambatan radikal bebas ekstrak etanol daun pecut kuda diperoleh nilai $\mathrm{IC}_{50}$ sebesar 74,32 \pm $0,71 \mathrm{ppm}$. Hal ini bermakna bahwa ekstrak etanol daun pecut kuda terbukti memiliki potensi sebagai antiradikal bebas DPPH. Nilai $\mathrm{IC}_{50}$ 50-100 ppm menunjukkan bahwa ekstrak etanol daun pecut kuda memiliki aktivitas antioksidan yang tergolong kuat (Molyneux, 2004). Jika dibandingkan dengan nilai $\mathrm{IC}_{50}$ vitamin $C$ pada penelitian ini yaitu sebesar 9,40 $\pm 0,07$ ppm, dimana nilai $\mathrm{IC}_{50}<50 \mathrm{ppm}$ menunjukkan bahwa 
vitamin C memiliki aktivitas antioksidan yang tergolong sangat kuat (Molyneux, 2004).

Perbandingan dengan penelitian sebelumnya dapat diketahui hasil dalam penelitian ini tidak sejalan dengan penelitian yang dilakukan oleh Ololade (2017) dan Rante et al (2020) yang mana hasil nilai $\mathrm{IC}_{50}$ pada penelitian tersebut secara berturut-turut yaitu sebesar 5,0 ppm dan 16,66 ppm. Pada kedua penelitian tersebut, sampel daun pecut kuda diekstrak menggunakan metode maserasi. Penggunaan metode maserasi dibandingkan metode sonikasi diketahui bahwa metode maserasi lebih baik dalam menghasilkan kualitas senyawa antioksidan. Hal ini dikarenakan pada maserasi tidak dipengaruhi oleh peningkatan suhu akibat proses ekstraksi seperti pada metode sonikasi.

Aktivitas penghambatan radikal bebas ekstrak daun pecut kuda meningkat seiring dengan meningkatnya senyawa yang bersifat antioksidan seperti fenolik, flavonoid, saponin dan tanin, tetapi setelah mencapai kondisi yang optimum, maka aktivitas penghambatan radikal bebasnya akan menurun selaras dengan penurunan senyawa yang bersifat antioksidan. Proses pemanasan mampu mengekstrak lebih banyak senyawa antioksidan, tetapi proses pemanasan yang berlebihan akan menyebabkan kerusakan aktivitas antioksidan (Kosakih, 2017).

Pada penelitian ini, penggunaan waktu ekstraksi dengan sonikasi yang terlalu lama hampir selama 1 jam juga dapat mempengaruhi aktivitas penghambatan radikal bebas oleh senyawa antioksidan. Semakin lama waktu ekstraksi maka semakin lama pula sampel akan terpapar oleh gelombang ultrasonik sehingga sel menjadi rusak. Hal ini dapat dibuktikan dari penelitian yang dilakukan oleh Sekarsari et al (2019) menyatakan bahwa perlakuan waktu ekstraksi daun jambu biji dengan gelombang ultrasonik berpengaruh sangat nyata $(\mathrm{P}<0,01)$ terhadap aktivitas antioksidan ekstrak daun jambu biji. Hasil yang diperoleh dari penelitian Sekarsari (2019) yaitu pada waktu ekstraksi selama 20 menit memberikan perlakuan yang terbaik berdasarkan persentase penghambatan radikal bebas ekstrak daun jambu biji yaitu $89,03 \%$ dengan nilai $\mathrm{IC}_{50}$ sebesar 3,55 $\mathrm{mg} / \mathrm{L}$. Selain itu, penelitian yang dilakukan oleh Ardiyanti (2017) menyatakan bahwa waktu ekstraksi dengan sonikasi selama 15 menit memberikan hasil penghambatan radikal bebas sebesar $48,11 \%$ dan lebih dari 15 menit memberikan sedikit penurunan pada persentase penghambatannya.

\section{Kesimpulan}

Berdasarkan penelitian yang telah dilakukan maka dapat disimpulkan bahwa ekstrak etanol daun pecut kuda memiliki aktivitas penghambatan radikal bebas dengan nilai $\mathrm{IC}_{50}$ sebesar 74,32 $\pm 0,71 \mathrm{ppm}$ dan aktivitas aktivitas penghambatan radikal bebas vitamin $\mathrm{C}$ memiliki nilai dengan $\mathrm{IC}_{50}$ sebesar 9,40 $\pm 0,07 \mathrm{ppm}$. Intensitas aktivitas penghambatan radikal bebas pada ekstrak etanol pecut kuda tergolong kuat dan vitamin $\mathrm{C}$ tergolong sangat kuat.

\section{Daftar Pustaka}

Ardiyanti, M. R. (2017). Pengaruh proporsi pelarut dan lama waktu ekstraksi berbantu ultrasonik dibandingkan maserasi terhadap saponin biji mahoni (Swietenia mahagoni Jacq). Malang: Universitas Brawijaya.

Chandra, B., Rezza, P. S., Sestry, M. Z. A., \& Ridho, A. (2019). Skrining fitokimia dan aktivitas antioksidan ekstrak metanol daun kemangi (Ocimum tenuiflorum L.) dengan metode DPPH (1,1-difenil-2-pikrilhidrazil). Journal of Pharmaceutical and Sciences, 6(2), 1-8. Retreived from https://journaljps.com/index.php/jps/article/download/20/ $\underline{16}$

Dalimartha, S. (2000). Atlas tumbuhan obat Indonesia Jilid II. Jakarta: Trubus Agriwidya.

Dash, P. R. (2016). Phytochemical screening and pharmacological investigations on Hedychium coronarium. Hamburg: Anchor Academic Publising.

Dean, A. G. (2004). Vitamin C supplementation and urinary oxalate excretion. Rev Urol. 6(3), 167$170 . \quad$ Retreived from https://www.ncbi.nlm.nih.gov/pmc/articles/ PMC1472830/

Depkes RI. (2000). Parameter standar umum ekstrak tumbuhan obat. Jakarta: Departemen Kesehatan Republik Indonesia.

Kosakih, F. (2017). Pengaruh Jenis Pelarut, Suhu dan Lama Wakti Ekstraksi Terhadap Aktivitas Antioksidan Pada Ekstrak Daun Sirsak (Annona muricata L.) Serta Aplikasinya Dalam Produk Hard Candy. Semarang: Universitas Katolik Soegija Pranata.

Kumoro, A. C. (2015). Teknologi ekstraksi senyawa bahan aktif dari tanaman obat. Yogyakarta: Plantaxia. 
Maesaroh, K., Dikdik, K., \& Jamaludin, A. A. (2018). Perbandingan metode uji aktivitas antioksidan DPPH, FRAP dan FIC terhadap asam askorbat, asam galat dan kuersetin. Chimica et Natura Act, 6(2), 355-360. doi:

https://doi.org/10.24198/cna.v6.n2.19049

Molyneux, P. (2004). The use of the stable free radikal DPPH (1-1 diphenyl, 2-picrylhydrazyl) for estimating antioxidant activity. J.Sci. of Tech., 26(2). Retrieved from https://www.researchgate.net/publication/23 7620105_The_use_of_the_stable_radical_Diphe nylpicrylhydrazyl_DPPH_for_estimating_antio xidant_activity

Mulangsri, D. A. K., Aqnes, B., \& Endah, N. S. (2017). Aktivitas antioksidan fraksi dietileter buah mangga arumanis (Mangifera indica L.) dengan metode DPPH. Jurnal Pharmascience, 4(1), 83-93. doi: http://dx.doi.org/10.20527/jps.v4i1.5760

Oliva, C. R., \& Teresita, B. Z. (2015). Determination of secondary metabolites and antibacterial property of extract from the leaves of Stachytarpheta jamaicensis (L.) Vahl. Journal of Medicinal Plants Studies, 3(4), 79-81. Retrieved from

https://www.plantsjournal.com/vol3Issue4/Is sue_july_2015/3-3-36.1.pdf

Ololade, Z. S., Ogunmola, O. O., Kuyooro, S. E., \& Abiona, O O. (2017). Stachytarpheta jamaicensis leaf extract: chemical composition, antioxidant, anti-arthritic, anti-inflammatory and bactericidal potentials. Journal of Scientific and Innovative Research, 6(4), 119-125. http://www.jsirjournal.com/Vol6_Issue4_01.p $\underline{\mathrm{df}}$

Prasetyo, P., \& Inoriah, E. (2013). Pengelolaan budidaya tanaman obat-obatan (bahan simplisia). Bengkulu: Badan Penerbitan Fakultas Pertanian UNIB.

Qazi, A. M., \& Khurshid, I. M. (2018). Free radicals and their management. American Journal of Pharmacy and Health, 6(4), 1-10. doi: http://dx.doi.org/10.46624/ajphr.2018.v6.i4.00 $\underline{1}$

Raaman, N. (2006). Phytochemical techniques. New Delhi: New India Publishing Agency.

Rante, T. R. K., Simbala, H. E. I., \& Mansauda, K. L. R. (2020). Skrining fitokimia dan potensi antioksidan dari ekstrak daun tumbuhan ekor tikus (Stachytarpheta jamaicensis L) dengan metode 1.1 Diphenyl-2-Picrylhydracyl (DPPH). JURNAL MIPA, 9(2), 91-96. doi: https://doi.org/10.35799/jmuo.9.2.2020.2 $\underline{9000}$

Riordan, H. D., Casciari, J. J., Gonzalez, M. J., Riordan, N. H., Miranda-Massari, J. R., Taylor, P., \& Jackson, J. A. (2005). A pilot clinical study of continuous intravenous ascorbate in terminal cancer patients. Puerto Rico Health Sci. J, 24(4), 269-276. Retrieved from https://pubmed.ncbi.nlm.nih.gov/16570523/

Sekarsari, S., Widarta, I. W. R., \& Jambe, A. A. G. N. A. (2019). Pengaruh suhu dan waktu ekstraksi dengan gelombang ultrasonik terhadap aktivitas antioksidan ekstrak daun jambu biji (Psidium guajava L.). Jurnal Ilmu dan Teknologi Pangan, 8(3), 267-277. Retrieved from https://ojs.unud.ac.id/index.php/itepa/articl e/download/53458/31644 